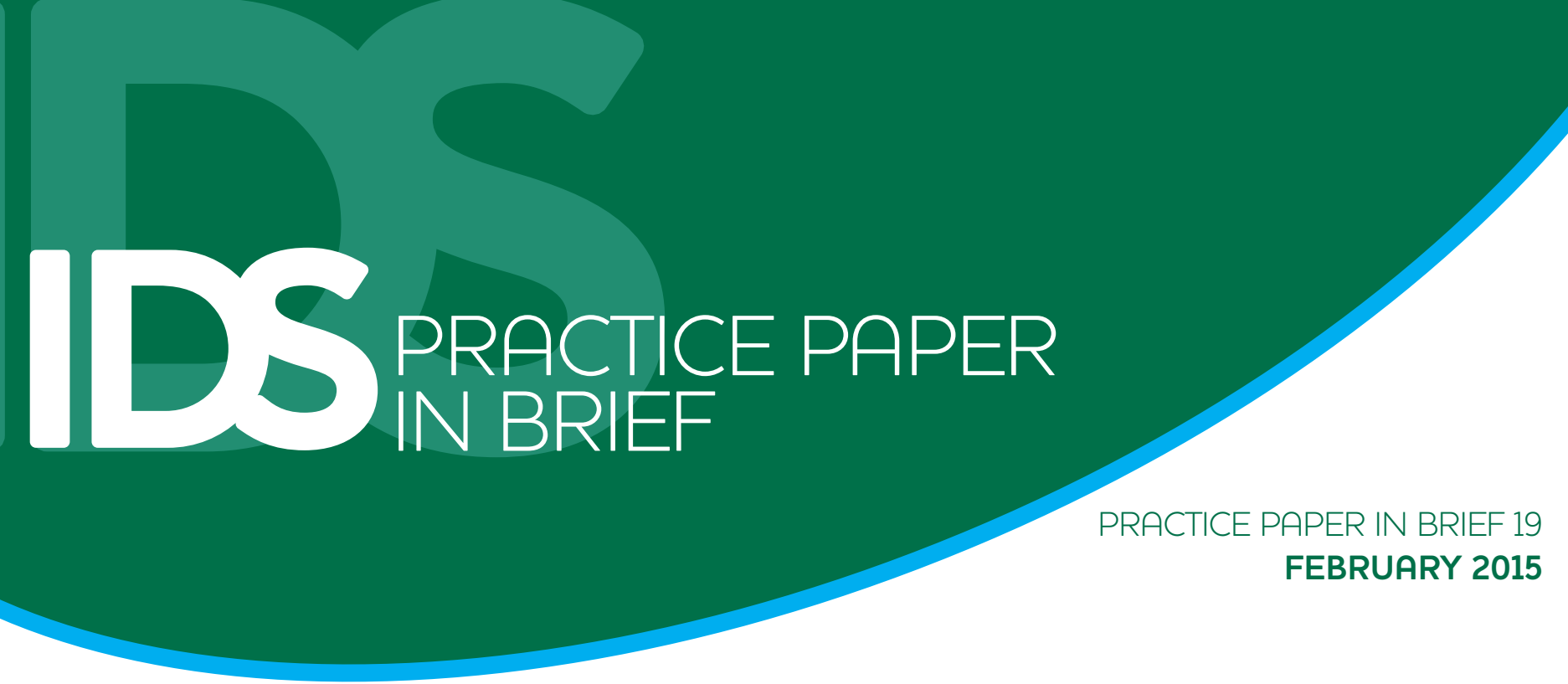

\title{
Return of the Rebel: Legacies of War and Reconstruction in West Africa's Ebola Epidemic
}

The spread of Ebola in West Africa centres on a region with a shared recent history of transnational civil war and internationally led post-conflict reconstruction efforts. This legacy of conflict and shortcomings in the reconstruction efforts are key to understanding how the virus has spread. The dynamics of warfare tied into and accentuated the state's remoteness from many people. Ebola has simply unmasked persisting deep public suspicion and mistrust of the state, laying bare the limits of post-conflict reconstruction to transform state-society relations. The reconstruction emphasis on rehabilitating pre-existing governance structures - such as the paramount chieftancy in Sierra Leone - did not redress deeply rooted social inequalities, with the result that many people have been marginalised. Ebola's impacts threaten to undo some of the advances made since the wars ended in Sierra Leone and Liberia, yet there are critical lessons to learn about how to better support societies shaped by violence and war.

\section{Introduction}

Wars and their aftermath are rightly a prominent thread of analysis of the Ebola epidemic in West Africa. To many it is unsurprising that a disease like Ebola would spread in environments inscribed with a history of transnational civil war and chronic violent insecurity. Before the disease spread spiked in 2014, Liberia was slowly recovering from two civil wars stretching over a 14-year period from 1989 to 2003. More than 250,000 people were killed in the conflicts, nearly a tenth of its pre-war population. Sierra Leone was recovering from an 11-year civil war that killed more than 50,000 and displaced more than two million people. Even after the wars ended, many areas of the Mano River Union (Guinea, Liberia, Sierra Leone and Côte d'Ivoire) continued to be afflicted by violent insecurity for several years. This fits a pattern of previous Ebola outbreaks to date in peripheral rural areas with complex legacies of violence, rebellion and a weak state presence, such as South Sudan, eastern Democratic Republic of Congo and western Uganda.

Thus, it seems fitting that war has become a metaphor to describe Ebola's spread from its first index case in the agrarian hinterlands of southern Guinea into neighbouring Sierra Leone and Liberia. In September, the Liberian Finance Minister Amara Konneh said Liberia is at 'war with an enemy we don't see,' (Ohlheiser 2014). Residents of Liberia's capital Monrovia have referred to Ebola as the 'invisible rebel', with one telling a western journalist, 'when war was here, you could see the soldiers coming, you could see the bullets flying and striking. You could run and protect yourself. But now, there's no way to know where Ebola is or whom it will hit' (Breen 2014). In Sierra Leone's capital Freetown residents have noted the similarities between Ebola's spread and how violence progressed during the country's civil war, advancing westwards from the forested periphery of Kailahun district in 1991 before ending in Freetown a decade later (Roy-Macaulay 2014).

While the region's history of civil war and violence has been a tableau against which the horrifying impacts of Ebola are brought into even starker relief, political leaders and security analysts have noted that the epidemic could hasten political collapse and, even worse, social breakdown. In comments widely covered by the international press, the Liberian Information Minister Lewis Brown told reporters in September that the slow response to the virus could push the region back into conflict, adding that 'the effect of Ebola is being seen not just as a public health situation but it is 
also a political situation' (Gordts 2014). Margaret Chan, Director General of the World Health Organization, worried openly that 'I have never seen an infectious disease contribute so strongly to potential state failure. I have never seen a health event threaten the very survival of societies and governments in already very poor countries' (Obaji Ori 2014).

To a great extent, this alarmist discourse of warfare abetting a regional epidemic abetting state collapse was tactical in order to push wealthy countries to step up their Ebola responses. Yet, it also raises serious questions for development that will be debated long after the worst of the crisis subsides. How do histories of violence influence contexts for development long after war is officially declared over? How should conflict legacies be understood and approached? How can post-conflict governments and their development partners better support societies shaped by violence and war?

\section{War legacies in Sierra Leone and Liberia}

The remoteness of the state from the daily lives of most Sierra Leoneans and Liberians is one of the most significant conflict legacies seen in the current Ebola epidemic. The youthful population of both countries means that most people's relationship with the state was configured during and through years of warfare. Yet, even before the outbreak of war, structural adjustment reforms hollowed out state structures that were meant to provide health care, education, training and other social support. Writing about the regime of Said Barre in Somalia, whose fall in 1991 ushered in a period of protracted war that is still ongoing, the late anthropologist Virginia Luling observed that what had collapsed was not a functioning state but rather an oppressive regime that 'was suspended above a society that would never have produced it and did not demand it' (Bradbury 2011). While describing a context across the continent, Luling's description could neatly encapsulate the relationships that prevailed between states and societies in Sierra Leone and Liberia before the onset of widespread conflict.

Paul Richards notes that the end of the Cold War brought about a crisis of the patrimonial state in Africa, causing it to shrink both physically as well as sociologically, in terms of the groups it could afford to patronise. In Sierra Leone, this meant depleting investment in social services - especially in education. As the state retreated and the country's agrarian interior was left to languish, insurgency incubated along the country's border with Liberia. As years passed, insurgents meted out violence in remote borderland chiefdoms that were inaccessible by the road network in either country. 'Lacking schools or other state facilities, these communities are a law unto themselves' Richards noted in 1996 (1996: 46).

\section{The end of war but persisting insecurity}

Although there are concerns that the virus threatens statehood in the region, the 'state' that is threatened is something that has been removed from the everyday lives of most Liberians and Sierra Leoneans for decades, failing to provide for or deliver their basic needs. In rural areas at least, clinics and dispensaries are distant or non-existent, with many people instead seeking health care from traditional healers and drug peddlers. Schools are overcrowded and teachers few. The condition of roads is poor, with the existing network meant to help extract the region's mineral wealth rather than support agrarian economies.

There were many notable gains in human development since the wars ended, not least significant reductions in maternal and infant deaths and in expanding access to education. Still, even after the wars ended, life remained deeply insecure for most people and violence continued to affect many. Sharon Abramowitz (2011: 27) describes post-conflict life in Liberia as being 'outside the law, in search of law and order.' She describes people who were poorer than when the war began and dispossessed of their lives, explaining that 'their personal connections to pre-war communities, ethnicities, and identities were more abstract than many liked to admit' (ibid.: 25).

Post-conflict life is also tenuous for many Sierra Leoneans, but especially its young people. The anthropologist Danny Hoffman shows that even when the militias were disbanded, 'the pressures and forces that assembled these men and deployed them in violence were still very much in existence in the rubber plantations, diamond mines, city streets and in the political party offices.' Hoffman's key point is that the lives of young people were qualitatively similar on both sides of the war and peace divide (Hoffman 2011: xii). By necessity, most people continued to rely on their own social networks and informal institutions to meet their needs.

\section{Post-conflict darlings?}

Before the current Ebola outbreak in West Africa, the apparent 'success' of state-building support in Sierra Leone and Liberia was celebrated in some corners. Yet, even following Sierra Leone's peaceful elections in 2012 - the first post-war election the country organised itself - the limits of state-building were becoming more apparent. In both countries, reconstruction programmes were externally driven processes, with a multiplicity of disparate United Nations 
$(U N)$ agencies and other international humanitarian organisations managing much of the assistance that was intended to improve basic welfare. The experience on the ground for many ordinary people however was one of uncertainty and ambivalence. As Richards et al. have noted, reconstruction programmes have failed to address the fundamental agrarian and chieftaincy structures and related issues such as lack of rights for young people to land, resources, social opportunities such as marriage, and control over labour, that fuelled the wars in the first place (Richards et al. forthcoming).

While reconstruction efforts did bring very real improvements in access to health and education, and while widespread conflict has been avoided, more than ten years of state-building have not fundamentally altered the perceptions of a remote state. Thus, early on in the outbreak, in Sierra Leone, fears circulated that Ebola was a government plot to depopulate the opposition-supporting east. In Liberia, when President Ellen Johnson Sirleaf ordered a quarantine for West Point - Monrovia's largest slum - local residents who attempted to remove a barricade were fired on by soldiers, accentuating feelings that the quarantine was an attack on the area's poor slum-dwellers, rather than a studied measure to contain the virus's spread.

Early responses to the virus in Sierra Leone and Liberia, including quarantines, aggressive policing, closed borders and other restrictions on people's movements, hark back to military controls deployed during the region's long wars, thereby further eroding trust and confidence in public authorities. Further, re-integration of Ebola survivors is facing some of the same kinds of societal problems as the re-integration of rebels; both are seen as having had 'asocial' contact with unknown forces, and both incite anxiety.

For governments in both countries, and their development partners, advancing reconstruction and recovery will again be key public policy objectives once the Ebola epidemic recedes. The formal end of UN peace operations in Sierra Leone in March 2014 momentarily highlighted the seeming success of reconstruction efforts in the region. However, evidence abounds that many people were not the 'resilient' subjects as typecast in so much post-conflict literature and were in fact struggling to 'get by' (Abramowitz 2011). Indeed, both Sierra Leone and Liberia ranked near the bottom of many human development indicators, even after a massive decade-long development-humanitarian operation.

Recovery from war dwarfs programme-defined post-conflict reconstruction periods. In particular, much more needs to be done to address the remoteness of the state from the lives of most people. This condition pre-dates civil wars in the region, meaning the challenge is not simply to recreate governance structures that pre-date conflict. The implicit emphasis of 'reconstruction' on piecing back together a normative social and political order only underlines the need for greater efforts that break the mould. Thus, Ebola's legacy in West Africa must be more than unmasking the limits of externally led state-building and reconstruction. The nettle must be grasped to seek more transformative change in the region's political and civil societies.

\section{Further reading}

Abramowitz (2014); Breen (2014); Gordts (2014); Hoffman (2011); Obaji Ori (2014); Ohlheiser (2014); Richards (1996). 


\section{Return of the Rebel: Legacies of War and Reconstruction in West Africa's Ebola Epidemic}

\section{References}

Abramowitz, S. (2014) Searching for Normal in the Wake of the Liberian War, Philadelphia: University of Pennsylvania Press

Bradbury, M. (2011) Mysomaliland.Com, http://mysomaliland.wordpress.com/2011/12/27/mark-bradburycomments-for-becoming-somaliland/ (accessed 25 February 2013)

Breen, L. (2014) 'Fighting Ebola, Liberia's "Invisible Rebel”', Washington Post, 29 August

Gordts, E. (2014) 'Top Liberian Official Warns Ebola Crisis May Plunge the Country Back into Conflict', Huffington Post, 24 September

Hoffman, D. (2011) The War Machines: Young Men and Violence in Sierra Leone and Liberia, Chapel Hill: Duke University Press

Obaji Ori, K. (2014) 'Liberia: Ebola Threatens Statehood Success, Post Civil War,' The Africa Report, 14 October Ohlheiser, A. (2014) 'Ebola is "Devouring Everything in its Path." Could it Lead to Liberia's Collapse?', Washington Post, 11 September

Richards, P. (1996) Fighting for the Rainforest: War, Youth and Resources in Sierra Leone, London: International Africa Institute with James Currey/Heinemann

Richards, P.; Amara, J.; Ferme, M.C.; Kamara, P.; Mokuwa, E:; Sheriff, A.ı.; Suluku, R. and Voors, M. (forthcoming) 'Social Pathways for Ebola Virus Disease in Rural Sierra Leone, and Some Implications for Containment', PLOS Neglected Tropical Diseases, http://blogs.plos.org/speakingofmedicine/files/2014/10/Richards-et-al.1.pdf Roy-Macaulay, C. (2014) 'Ebola Cases Rise Sharply in Western Sierra Leone', Associated Press, 21 October

Institute of Development Studies

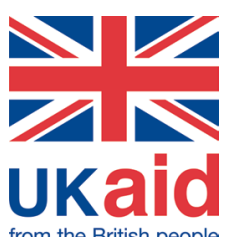

Institute of Development Studies Brighton BN1 9RE UK

T+44 (0) 1273606261 F + 44 (0) 1273621202 E ids@ids.ac.uk W www.ids.ac.uk

\section{Credits}

This Practice Paper In Brief was written by Jeremy Lind (IDS) and Johnny Ndebe (Carter Centre, Monrovia, Liberia). It was produced as part of the IDS Strengthening Evidence-based Policy programme, funded by UK Aid from the UK Department for International Development. The opinions expressed are those of the authors and do not necessarily reflect the views of IDS or the UK government's official policies.

Readers are encouraged to quote and reproduce material from issues of Practice Papers in Briefs in their own publications. In return, IDS requests due acknowledgement and quotes to be referenced as above.

(c) Institute of Development Studies, 2015

AG Level 2 Output ID: 560 